\title{
SEBUAH PENDEKATAN ONTOLOGIS DALAM MEMAHAMI FILSAFAT SIVA SIDDHANTA
}

\author{
Oleh :
}

I Gusti Made Widya Sena

Dosen pada Fakultas Brahma Widya IHDN Denpasar

\begin{abstract}
:
Hindu religion as one of the religions that has complexity of philosophy in the development of his doctrines using the basis of religious knowledge, direct views and conclusions as a process of philosophical thinking.

Siva Siddhanta is the core or conclusion of the Siva doctrines that describes various concepts in it such as cosmology, metaphysics, theology, philosophy until the concept of unity with God.

The ontological perspective of Siva Siddhanta philosophical system derived from the essence of Siva as the ultimate reality. This is final doctrine and conclusion from Siva is known as Siva Siddhanta. Siva Siddhanta is a essence of Vedanta. Siva is the ultimate reality, it is eternal, without being, free, one, without beginning and end, without cause. Siva pervades the whole world with his Sakti, she uses Sakti as the energy of consciousness of Siva, which is actually the body Siva
\end{abstract}

Keywords : Ontology, Philosophy and Siva

\section{PENDAHULUAN}

Secara harfiah kata filsafat berasal dari bahasa Yunani, "philosophia" yang berarti mencintai kebijaksanaan. Arti kata dari mencintai kebijaksanaan adalah mengerahkan seluruh daya intuisinya untuk mencari, memahami dan menemukan tujuan yang dicita-citakan dan juga mengimplementasikannya dalam kehidupan sehari-hari.

Mencintai kebijaksanaan memiliki alur berpikir dengan logika yang bebas dan tidak terbatas namun sistematis, karena tidak hanya terbatas pada ruang lingkup dalam membangun dan mengembangkan cara berpikir logika melalui metode dan hipotesa saja, melampaui dari itu mencintai kebijaksanaan juga mengambil ruang rasa dari dalam hati yang digunakan untuk menghubungkan berbagai asumsi yang muncul di permukaan.

Agama Hindu sebagai salah satu Agama yang memiliki kompleksitas filsafat dalam perkembangan ajarannya menggunakan dasar dari doktrin pengetahuan agama, pandangan langsung dan pengambilan kesimpulan sebagai proses berpikir filsafat yang hakiki.

Sebagian besar dari sistem filsafat Hindu membicarakan tentang hakikat Tuhan dalam relasinya dengan manusia dan alam semesta. Salah satunya adalah ajaran filsafat dari Siva Siddhanta sebagai bagian dari Weda Smrti yang juga menyentuh aspek ini dalam rangka mencari dan memahami realita di dunia.

Siva Siddhanta merupakan inti atau kesimpulan dari ajaran Siva yang menjabarkan berbagai konsep didalamnya seperti: kosmologi, metafisika, teologi, filsafat hingga konsep penyatuan sebagai cara manusia dalam mencapaiNya.

Berdasarkan latar belakang di atas, penulis tertarik mengangkat tulisan ini karena penulis ingin mengetahui awal dan perkembangan filsafat Siva Siddhanta. 


\section{PEMBAHASAN}

\subsection{Perkenalan Filsafat Siva Siddhanta}

Untuk mengetahui hakekat Siva Siddhanta, maka hal yang utama untuk mengenalNya adalah melalui pengetahuan dan mengimplementasikan ajaranNya yang benar dalam kehidupan sehari-hari. Untuk itu agar lebih mudah dalam memahamiNya, pengetahuan mengenai hakekat Siva Siddhanta akan dipisahkan terlebih dahulu, yakni pengetahuan akan keberadaan Śiva dan ajaran Siddhanta. Berikut ini adalah proses pendakian filsafat Siva Siddhanta:

\subsubsection{Sudut Pandang Filsafat Ajaran Siva Sid- dhanta}

Ajaran filsafat Siva Siddhanta membutuhkan pemahaman yang alami tentang pemikiran umum dari jiwa filsafat yang dilatar belakangi oleh pandangan filsafat India. Pemikiran sistematis berkembang di India berasal dari sumber asli terkait sikap terhadap kehidupan yang dapat digambarkan sebagai agama dalam arti yang luas dari istilah (Siva Siddhanta) ini. Refleksi filosofis ini dihadapkan dari awal dengan dunia makna yang religius. Dengan agama kita mengacu pada unsur-unsur dalam struktur kesadaran sendiri, bukan barang atau usaha budaya yang sampai pada tahap tertentu dalam sejarahnya mengandung kepentingan.

Agama adalah sikap disposisi dasar yang dari segi kedalamannya mengandung kehidupan dunia yang suci. sebagai ciri dasar struktur eksistensi manusia itu sendiri. Memahami refleksi filosofis sebagai fungsi agama dan kehidupan religius yang maknanya dipahami dalam kerangka struktur ketimbang sejarah dan budaya.

Konsep filsafat tersirat dalam penalaran filosofi India yang perlu dipahami secara utuh dan dihargai dalam hubungannya dengan sains, budaya, peradaban, kehidupan masyarakat, ras atau bangsa.

Filsafat sejauh ini adalah usaha manusia yang dipengaruhi oleh faktor-faktor di atas, yang dalam menjabarkannya dari kehidupan budaya umum, terutama dari jalur filsafat banyak memiliki resiko masalah. Namun doktrin filsafat memiliki kualitas abadi tentang hal tersebut, yakni tentang ketidakberdayaan mendasar dari pencarian manusia yang bertepatan dengan inti alam manusia yang tidak pernah mengalami perubahan.

Filsafat adalah dinamika dengan cara yang peka menjadi suatu pengalaman yang tumbuh secara terus menerus dan berkelanjutan. Filsafat membantu mewujudkan apa saja yang diperlukan, yaitu integrasi dan penyerahan diri. Sumber pengetahuan ini hampir sama dengan pemikiran akan filsafat sejati yang menjadikan pengalaman keseharian sebagai kesatuan sadar dalam mencapai pengalaman kebahagiaan.

Ajaran Siva Siddhanta bukan merupakan sebuah sistem keyakinan atau kepercayaan yang besar melainkan sebuah sistem filosofis yang hidup dan berkembang hingga saat ini. Filsafat Siva Siddhanta yang hingga kini masih eksis adalah buah dari pemikiran dan kehidupan para penyusun filsafat ini. Oleh karena itu, sama pentingnya dengan relevansinya karena ajaran ini sangat kuno dan tradisional. Sebuah penyelidikan terhadap Siva Siddhanta sebaiknya tidak hanya menitikberatkan pada ilmu arkeologi untuk sejarah atau filsafatnya saja tapi juga dapat dikaji dengan pengkajian mendalam sebagai pandangan dan kehidupan Siva Siddhanta itu berada.

Metode pendekatan yang digunakan oleh ajaran Siva Siddhanta dalam filsafatnya sama dengan metode yang digunakan dalam sistem filsafat klasik India. Metode yang digunakan adalah metode yang menggunakan kejelasan berpikir terhadap universalitas dan kebutuhan. Sistem Siva harus dipahami sesuai dengan metode pendekatan ini.

Filsafat ajaran Siva Siddhanta tidak dipahami dari bagian awal, melainkan di bagian tengah, yang masing-masing dari bagiannya terintegrasi dan holistik. Ikatan dan belenggu duniawi sebagai bentuk pengaruh maya hanya dapat dihilangkan dengan peran Siva sebagai tujuan akhir filsafat ini. Ini adalah tiga prinsip yang merangkul keseluruhan aspek ajaran tersebut. Dan keseluruhan pemahaman dari aspek ini dibutuhkan untuk memahami prinsip dasar ajaran filsafat Siva Siddhanta. Hubungan 
yang mendalam diantara ketiga prinsip ini merupakan unsur utama dimana satu dan lainnya sangat berkaitan dan merupakan keseluruhan dari sistem yang ada.

Ketiga unsur ini (ikatan/belenggu, maya dan Siva) tidak dapat pahami secara terpisah dengan memahaminya satu persatu dari mereka. Hal ini dilakukan secara sadar untuk menunjukkan kebenaran akan simbol terhadap unsur Tuhan, dunia dan diri.

\subsubsection{Konsep Siva Siddhānta}

Filsafat Siva merupakan satu cabang dari agama, di mana gambaran perbedaannya adalah pemujaan pada bentuk phallus / lingga Śiva. Siva sebagai satu agama telah ada sejak jaman prasejarah, terbukti dari hasil penggalian arkeologi yang diketemukan di Harappa dan Mahenjodaro dan memiliki sejarah kurang lebih 5.000 tahun lamanya.

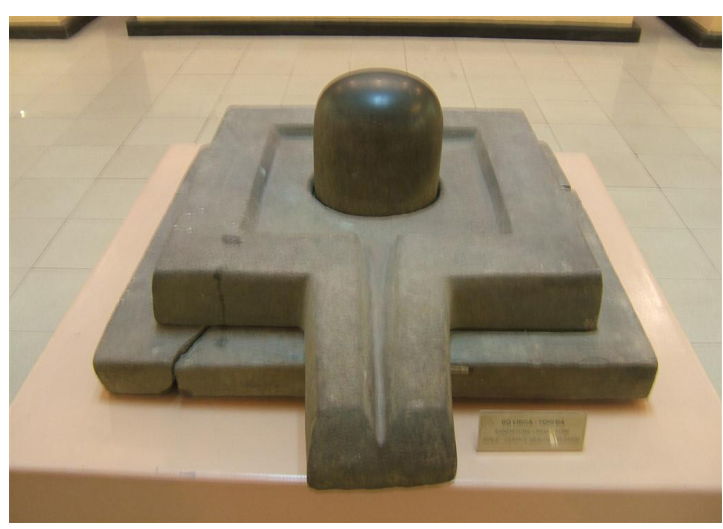

Gambar 1. Lingga-Yoni

(Simbol Siva dan Sakti juga perlambang kesuburan)

Sistem Siva Siddhanta adalah saringan dari esensi Vedanta. Tuhan Siva adalah realitas tertinggi. Ia adalah abadi, tanpa wujud, bebas, ada dimana-mana, satu, tanpa awal, tanpa sebab, tanpa cacat, ada sendiri, selalu bebas, selalu murni. Tidak terbatas oleh waktu, kebahagiaan tanpa batas dan kecerdasan tanpa batas. Siva meresapi seluruh dunia dengan SaktiNya. Ia mempergunakan SaktiNya. Sakti adalah energi kesadaran dari Siva, yang sesungguhnya merupakan badan dari Siva.

Di dalam Siva Siddhanta terdapat 36 Tattwa yang 24 tatwanya dikenal sebagai atma tattwa, 7 sebagai widya tattwa dan sisanya 5 sebagai Siva tattwa. Ke 24 atma tattwa adalah 5 unsur dasar (panca maha bhuta), 5 tan matra (suara, raba, wujud, rasa dan bau), 5 organ perasa (telinga, kulit, mata, lidah dan hidung), 5 organ penggerak (pengucap, tangan, kaki, anus dan kemaluan), 1 organ dalam dan ahamkara, buddhi dan guna. Widya tattwa terdiri dari 7 , yakni: purusa, raga, vidya, kala, niyati, waktu dan tidak murni. Ke 5 Siva tattwa adalah suddha widya, Isvara, Sada Siva, Sakti dan Siva.

Konsep ajaran Siva Siddhanta, baik itu terkait dengan penentuan lingkup dan makna kelihatannya sejak awal berputar di area logika filosofis di dalam dan di luar kelompok ajaran filsafat India. Selain itu Siva Siddhanta menemukan kebenaran/keyakinan yang lain. Hal ini tentunya memerlukan analisis yang hati-hati karena sangat menentukan secara sejarah dan doktrin untuk pandangan tentang makna Siva Siddhanta.

Ke lima aktivitas (Panca Krtya) dari Tuhan adalah srsti (penciptaan), sthiti (memelihara), samhara (mengembalikan), tirobhava (tudung) dan anugraha (karunia). Simbol ini merupakan personifikasi dari Brahma, Wisnu, Rudra, Maheswara dan Sada Siva.

Menurut Sivananda (2006:47), di dalam mantra Panca aksara "Nama Sivaya". Kata "Na" adalah kekuatan memeriksa dengan keras dan teliti dari Tuhan yang membuat jivatman bergerak di dunia, kata "Ma" adalah ikatan yang mengikat jiwatman di dalam samsara roda kelahiran dan kematian, kata "Si" adalah simbol Siva, Va berlaku bagi karunia dan Ya berlaku bagi jivatman. Jika jivatman kembali kepada "Na" dan "Ma" ia akan tenggelam dalam duniawi. Jika jiwatman mengasosiasikan dirinya dengan "Ya" ia akan bergerak menuju Siva.

\subsubsection{Pati, Pasu dan Pasa}

Siva Siddhanta adalah formula filosofis yang berkelanjutan dari tujuan utama dan wawasan tentang kesadaran religius. Filsafat Siva Siddhanta kelihatannya seperti pluralistik dalam arti filsafat yang tidak absolut mengandung tiga unsur ideal yang tidak dapat direduksi, antara lain: pati, pasu dan pasa. 
Pati, pasu dan pasa merupakan simbol dari Tuhan, diri sendiri dan dunia, karena itu berbeda secara logis. Pati dan pasa memerlukan pasu yang mengikat. Itu mengapa filsafat Siva Siddhanta merumuskan dan memiliki keyakinan kepada tiga unsur tersebut sebagai yang tertinggi. Pati, pasu dan pasa seperti itu dengan menyiratkan hubungan dan keterikatan antara satu dengan lainnya, yang membedakan diantara ketiganya adalah dari aspek ontologis dan epistemologisnya.

Pati adalah Śiva. Śiva adalah tidak terbatas, kekal, satu tanpa duanya. Ia tidak dapat berubah dan tidak dapat dibagi. Ia adalah obyek dari seluruh Veda dan Agama untuk menjelaskan konsep dari Tuhan (Pati), dan jivātman yang terikat (Paśu), yang arti sebenarnya adalah dunia (Paśa).

Siva menguasai seluruh dunia dengan SaktiNya. Siva bekerja dengan SaktiNya. Sakti merupakan energi kesadaran dari Siva dan merupakan tubuhNya. Siva adalah penyebab pertama di dunia, Sakti adalah penyebab instrumentalnya dan Maya adalah penyebab materinya.

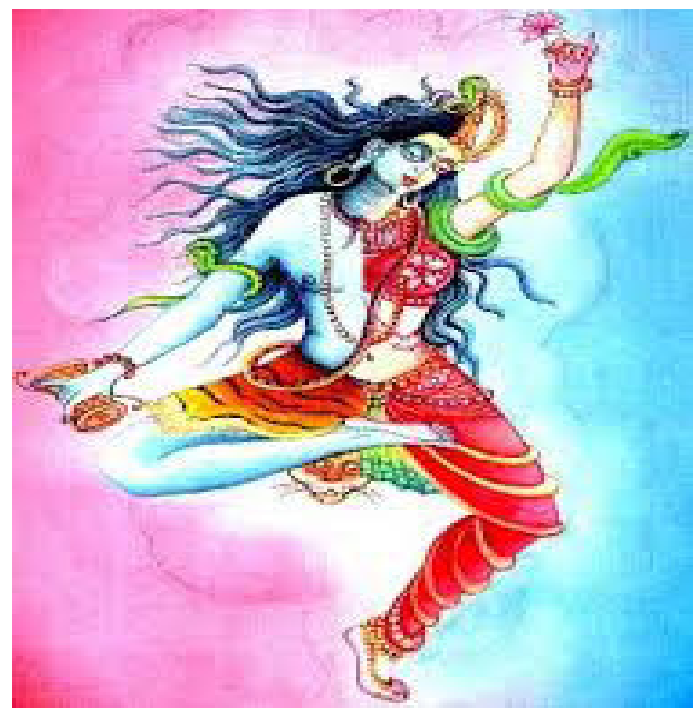

Gambar 2. Konsep Ardhanareswari (Penyatuan Siva dan Sakti)

Paúu adalah jivàtman seseorang yang tenggelam dalam lumpur saýsara. Ia diberikan tubuh untuk melakukan baik dan buruk dan dilahirkan sebagai makhluk yang lebih rendah dan yang lebih tinggi sesuai dengan hakekat karma.
Paúa adalah ikatan. Jaringan ikatan dibedakan kedalam avidyà dan anavamala, karma dan màyà. Anavamala adalah keakuan, ini adalah noda yang disebabkan oleh pengertian palsu dari keterbatasan jivàtman yang dimiliki. Jiwatman membayangkan dirinya sendiri adalah terbatas dan keterbatasan dari tubuh, keterbatasan dari pengetahuan dan kekuatan. Ia salah menyamakan dirinya sendiri dengan badan yang dapat hancur dan kesalahan-kesalahan yang mengganggap bahwa tubuh adalah dirinya yang sejati dan melupakan hakikat hakiki dari keIllahian.

Karma adalah penyebab dari badan dan banyak pengalaman badan akan kelahiran dan kematian. Ia adalah tanpa awal dan penyebab yang mengaitkan kesadaran jiwatman dengan badan yang tidak memiliki kesadaran. Karma membantu awidya, yang dilakukan dengan bantuan pikiran, perkataan dan perbuatan. Mengambil wujud pahala dan dosa dan menghasilkan kegembiraan dan duka. Karma tidak dapat dihancurkan karena ia adalah hasilnya.

Di sisi filosofis ini mengekspresikan diri dalam perbedaan yang jelas antara pati, pasu dan pasa. Pasu memiliki identitas dalam mewujudkan kesabaran yang diraihnya dengan menaklukkan pasa. Pati adalah roh transcendent yang pada saat bersamaan tetap dalam kondisi kehidupan yang terbatas dari keberadaan pengaruh dan ikatan maya. Maya berkembang menjadi prinsip yang halus dan kemudian terpengaruh sehingga menjadi kotor.

Sebagai imanen di dalamnya, Pati adalah membantu manusia dari kondisi perbudakan maya yang membatasinya. Melalui Pati pada akhirnya manusia dapat bebas dan keluar dari maya dan sebab musabab karma phala.

\subsection{Ajaran Siva Siddhanta}

Siwa Siddhanta adalah dasar dari semua kesadaran dan tindakan. Setiap ajaran Siva Siddhanta biasanya mempelajari tentang pati, pasu dan pasa. Dan diluar tiga aspek itu ajaran filsafat ini umumnya juga mempelajari tentang: 


\section{Jи̃̄̄na}

Adalah dikaitkan dengan filsafat, termasuk masalah metafisika, epistimologi dan etika; jnana juga mencakup tentang daya untuk mengetahui dan aspeknya adalah Isvara

\section{Yoga}

Adalah dikaitkan dengan pelaksanaan Yoga, yang diperlukan guna mewujudkan tujuan yang dinyatakan oleh filsafat. Ia memberikan rincian yang diperlukan dalam disiplin Yoga, karena hal yang demikian itu tidak dapat diketemukan dimanapun juga. Ia memberikan kemajuan pada tradisi Yoga yang diimpun oleh Rsi Patanjali dalam yoga sùtra-nya, bukan dalam espek filsafatnya tetapi dalam aspek peleksanaannya;

\section{Kriy $\bar{a}$}

adalah daya menggenakan sesuatu atau setiap bentuk, yang dalam aspek ini dikenal sebagai sadvidyā atau śuddhavidyā. Alam semesta merupakan suatu pembukaan (unmesa) atau pengembangan (prasara) dari yang Tertinggi atau Śakti .

Kriya juga berkaitan dengan cara-cara membangun kuil dan pahatan patung para devatā yang akan dipasang dikuil tersebut. Ia mencatat tentang tradisi arsitektur dan pahatan yang berhubungan dengan masalah pembuatan bangunan kuil dan pembuatan patung dan bagian Śaivāgama ini tampaknya telah dijadikan dasar dari uraian tentang arsitektur, yaitu $S a-$ marāgana Sùtradhara oleh raja Bhoja, yang menulis banyak sekali karya tulis tentang filsafat Śaiva antara lain Tattwa Prakāśikā, dan sebagainya.

\section{Caryā}

Adalah berkaitan dengan masalah pelaksanaan upacara atau ritual keagamaan.

\section{Iccha}

Adalah kehendak untuk berbuat ini atau itu, untuk menciptakan dan dalam aspek ini Dia dikenal sebagai Śadasiva atau Sādākhya

6. Ānanda

Adalah merupakan kebahagiaan mutlak, yang disebut svatantrya atau kehendak mut- lak, yang mampu berbuat apapun tanpa bantuan dari luar dan dalam aspek yang tertinggi ini disebut dengan Śakti .

\section{SIMPULAN}

Sudut pandang ontologis dari filsafat Siva Siddhanta adalah keseluruhan dari sistem filsafat ini bersumber dari esensi Siva sebagai realitas tertinggi. Ajaran akhir atau kesimpulan dari Siva inilah yang dikenal dengan istilah Siva Siddhanta atau Siva Tattwa.

Metode yang digunakan dalam Siva Siddhanta adalah metode yang menggunakan kejelasan berpikir terhadap universalitas dan kebutuhan. Sistem Siva harus dipahami sesuai dengan metode pendekatan ini.

Siva Siddhanta merupakan saringan dari esensi Vedanta. Tuhan Siva adalah realitas tertinggi. Ia adalah abadi, tanpa wujud, bebas, ada dimana-mana, satu, tanpa awal, tanpa sebab, tanpa cacat, ada sendiri, selalu bebas, selalu murni. Tidak terbatas oleh waktu, kebahagiaan tanpa batas dan kecerdasan tanpa batas. Siva meresapi seluruh dunia dengan SaktiNya. Ia mempergunakan SaktiNya sebagai wujud energi kesadaran dari Siva, yang sesungguhnya merupakan badan dari Siva itu sendiri.

Siva Siddhanta adalah formula filosofis yang berkelanjutan dari tujuan utama dan wawasan tentang kesadaran religius. Filsafat Siva Siddhanta kelihatannya seperti pluralistik dalam arti filsafat yang tidak absolut mengandung tiga unsur ideal yang tidak dapat direduksi, diantaranya: pati, pasu dan pasa.

\section{DAFTAR PUSTAKA}

Maulana, Achmad. 2003. Kamus Ilmiah Populer. Yogyakarta: Absolut

Pendit, Nyoman S. 2007. Filsafat Hindu Dharma, Sad Darsana, Enam Aliran Astika (Ortodoks). Denpasar: Pustaka Bali Post

Pudja, G. 1984. Sraddha. Jakarta: Mayasari 2003. Bhagawad Gìtà (Pancama Veda). Surabaya: Paramita. 
Pudja, G., Rai Sudharta, Tjokorda. 2003. Manawa Dharmaúastra (Manu Dharmasastra). Jakarta: Mitra Jaya.

Sivananda. 2006. Tuhan Siva dan PemujaanNya. Surabaya: Paramitha.

Sura, I Gede. 2005. Siwa Tattwa. Denpasar : Tri Guna.

Tim, Penyusun. 1999. Siwa Tattwa. Pemerintah Daerah Tingkat I Bali Proyek Peningkatan Prasarana Kehidupan Beragama Terbesar di Daerah Tingkat II.

\section{Hindu. Denpasar}

Titib, I Made. 2003. Teologi dan Simbol-simbol Dalam Agama Hindu. Surabaya: Paramita.

2011. Teologi Dalam Susastra

Hindu. Surabaya: Paramita 